Hydraulic Engineering Repository

Ein Service der Bundesanstalt für Wasserbau

Keaton, Jeffrey R.; Mishra, Subhendu K.

Modified Slake Durability Test for Erodible Rock Material

Verfügbar unter / Available at:

https://hdl.handle.net/20.500.11970/100291

Vorgeschlagene Zitierweise / Suggested citation:

Keaton, Jeffrey R.; Mishra, Subhendu K. (2010): Modified Slake Durability Test for Erodible Rock Material. In: Burns, Susan E.; Bhatia, Shobha K.; Avila, Catherine M. C.; Hunt, Beatrice E. (Hg.): Proceedings 5th International Conference on Scour and Erosion (ICSE-5), November 7-10, 2010, San Francisco, USA. Reston, Va.: American Society of Civil Engineers. S. 743-748. 


\title{
Modified Slake Durability Test for Erodible Rock Material
}

\author{
Jeffrey R. Keaton ${ }^{1}$ F.ASCE, Ph.D., P.E. and Su K. Mishra ${ }^{2}$ M.ASCE, Ph.D., P.E.
}

${ }^{1}$ Senior Principal Engineering Geologist, MACTEC Engineering and Consulting, Inc., 5628 East Slauson Avenue, Los Angeles, CA 90040; PH (323) 889-5316; email: irkeaton@mactec.com

${ }^{2}$ Senior Technical Advisor, HDR, 2365 Iron Point Road, Suite 300, Folsom, CA 95630; PH (916) 817-4860; email: su.mishra@ihdrinc.com

\begin{abstract}
The slake durability index (ASTM D4644-08) measures the response of rock fragments to submerged tumbling action. This test was modified to eliminate oven drying, extend test-increment duration, and increase the number of test increments to better reflect conditions in rock-bed stream channels. The results are expressed as a linear dimension taken to represent equivalent scour depth and normalized cumulative power taken to represent equivalent stream power. Sample loss during the first test increment is dominated by rounding of fragment edges and corners; hence, it is disregarded. Subsequent test increments display a linear trend, the slope of which is defined as the 'geotechnical scour number'. The geotechnical scour number of thinly bedded siltstone is similar to an 'empirical scour number' calculated from measured scour and cumulative stream power for the same location. Scour numbers for other rock types were consistent with observed channel behavior suggesting that the modified slake durability test may be valuable for predicting scour at bridge sites.
\end{abstract}

\section{INTRODUCTION}

Scour of earth materials characterized by cohesion, cementation, or induration is cumulative and progressive, unlike cohesionless, granular soils which respond rapidly to peak hydraulic loading. Procedures for evaluating scour of sand-bed channels (e.g., Richardson and Davis, 2001) have been available for some time, but procedures for rock-bed channels are being developed by the authors of this paper through National Cooperative Highway Research Program Project No. 24-29.

Four modes of rock scour exist: 1) dissolution of soluble rocks, 2) cavitation, 3) quarrying and plucking of durable blocky rocks, and 4) grain-scale wear of erodible rocks. The rock-scour mode addressed in this paper is the gradual, but progressive grain-scale wear of erodible rock material. The example presented in this paper pertains to the Sacramento River at Redding, Shasta County, California, USA.

The purpose of this paper is to describe modifications to a standard test procedure (the slake durability index) and its applicability to rock scour. The first application of the slake durability test to rock scour was done in Oregon by Dickenson and Baillie (1999). These researchers modified the standard procedure and produced an abrasion number to describe the response of the rocks to the submerged tumbling action. We were impressed by their modifications and applied them in our own research. Dickenson and Baillie (1999) used stream power to represent hydraulic loading. We also use stream power because it combines all hydraulic parameters and can be accumulated meaningfully. The importance of stream power became clear to 
us during analysis of stream gage data, which led us to an 'empirical scour number'. This concept prompted us to express modified slake durability test results in equivalent stream power terms, which led us to a 'geotechnical scour number'.

\section{SLAKE DURABILITY TEST}

The slake durability index (ASTM D4644-08) is defined as "the percentage by dry mass of a collection of shale pieces retained on a $2.00 \mathrm{~mm}$ (No. 10) sieve after two cycles of oven drying and 10 minutes of soaking in water with a standard tumbling and abrasion action." The standard test calls for 10 roughly equidimensional fragments and a total specimen weight between 450 and 550 grams. The standard tumbling action is accomplished in a drum that rotates at 20 revolutions per minute. The standard drum is $100 \mathrm{~mm}$ long and $140 \mathrm{~mm}$ in diameter with sides composed of the $2-\mathrm{mm}$ mesh. The lower approximately $40 \%$ of the drum is submerged in a water reservoir; the axis of rotation is approximately $15 \mathrm{~mm}$ above the water surface.

A slake durability index of 5.3 was determined for siltstone from the Sacramento River at Redding, California, using the ASTM D4644 procedure. This index value indicates that $94.7 \%$ of the sample passed through the No. 10 sieve mesh after oven drying and two 10-minute cycles of submerged tumbling.

\section{ABRASION NUMBER}

Dickenson and Baillie (1999) determined that conventional slake durability results were unrepresentative of conditions in western Oregon streambeds underlain by degradable rock formations because the channel bottoms were never completely dry. They eliminated oven drying and extended test cycles to 30 minutes for the first 2 hours, and 60 minutes for the next 7 hours. Dickenson and Baillie (1999) determined sample weights using the 'saturated surface dry' procedure (ASTM C127) and disregarded the first few readings because of corner and edge rounding. They defined the slope of percent loss versus natural log cumulative time as an 'abrasion number' and correlated the abrasion number with observed channel degradation and cumulative stream power from stream gage data to develop a predictive relation. Two samples of siltstone were evaluated using these procedures as shown on Figure 1. The average abrasion number is 17.9 for the two samples shown on Figure $1 \mathrm{~b}$.

\section{SCOUR NUMBER}

\section{Empirical scour number}

Relatively long-term scour can be determined from repeated cross sections. California Department of Transportation provided data for the Market Street Bridge (State Route 273) over the Sacramento River at Redding. These data indicated about $1.52 \mathrm{~m}(5 \mathrm{ft})$ of pier scour occurred on the upstream side of the bridge over a 33.8-yr period. Daily flow series from a nearby gage (USGS Gage 11370500 at Keswick) were used to calculate a cumulative stream power of $3.37 \mathrm{e}+5 \mathrm{~W} / \mathrm{m}^{2}(23,100 \mathrm{ft}$ $\mathrm{lb} / \mathrm{s} / \mathrm{ft}^{2}$ ) during the same 33.8-yr period. We define the empirical scour number as the 


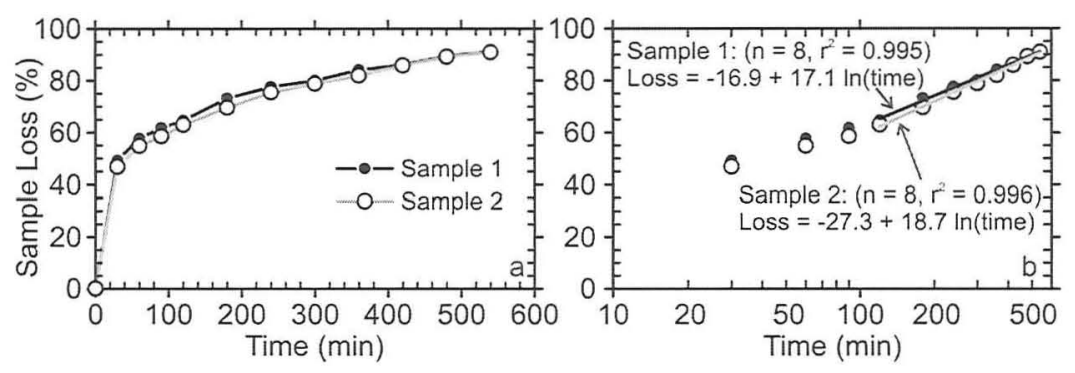

Figure 1. Slake durability results using the modification of Dickenson and Baillie (1999) for two samples of thinly bedded siltstone from the Sacramento River at Redding, Shasta County, California, USA. a. Arithmetic plot; b. Semi-log plot.

measured scour depth divided by stream power accumulated over the same period. An empirical scour number of $4.53 \mathrm{e}-6 \mathrm{~m} / \mathrm{W} / \mathrm{m}^{2}\left(0.000217 \mathrm{ft} / \mathrm{ft}-\mathrm{lb} / \mathrm{s} / \mathrm{ft}^{2}\right)$ was calculated for the Market Street Bridge.

\section{Geotechnical scour number}

We further modified the slake durability test to consist of 60 -minute increments for 9 hours and expressed the results as equivalent scour depth and equivalent stream power. The results must be normalized to an initial weight to permit direct comparison of energy dissipation demonstrated by different samples; we used an initial weight of 500 grams, which is the midpoint of the total sample weight range in ASTM D4644. Equivalent scour depth was calculated by dividing the weight loss during a test increment by the unit weight of the rock material determined by ASTM Procedure $\mathrm{C} 127$ for concrete aggregate to produce a loss volume, which was normalized by unit area to give a linear dimension taken to be equivalent scour depth.

Equivalent power was calculated by multiplying the average sample weight during the test increment times equivalent distance traveled during the test increment, dividing the product by cycle duration in seconds, and normalizing the result by the area of the bottom $1 / 8\left(45^{\circ}\right)$ of the test drum. The equivalent distance traveled is the circumference of the drum times the rate of rotation times the duration of the test increment. The normalizing area is arbitrary, but corresponds to the area of residence of the sample fragments during the test. Average sample weight times distance traveled is energy $(1 \mathrm{~N}-\mathrm{m}=1 \mathrm{~J})$; energy per unit of time is energy dissipation or accumulation, which is power $(1 \mathrm{~J} / \mathrm{s}=1 \mathrm{~W})$. Power per unit area matches the units of conventional stream power calculated as the product of hydraulic shear stress $\left(\mathrm{N} / \mathrm{m}^{2}\right.$ or $\left.\mathrm{lb} / \mathrm{ft}^{2}\right)$ and flow velocity $(\mathrm{m} / \mathrm{s}$ or $\mathrm{ft} / \mathrm{s})$, for example $1 \mathrm{~N}-\mathrm{m} / \mathrm{s} / \mathrm{m}^{2}=1 \mathrm{~W} / \mathrm{m}^{2}$.

The results of the modified slake durability test on the siltstone from the Market Street Bridge are plotted on Figure 2. The data plotted on Figure 1 represent the same tests on siltstone, but the 30-minute increment data were not used on Figure 2. The initial data points have the highest equivalent scour depth and equivalent stream power because sample fragments are being rounded and the sample 


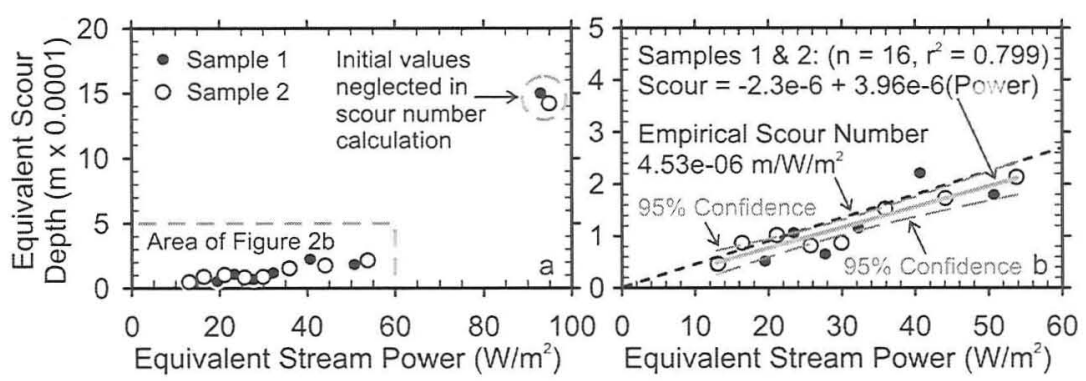

Figure 2. Modified slake durability results for two samples of thinly bedded siltstone from the Sacramento River at Redding, Shasta County, California, USA. Regression line slope on Figure $2 b$ is the geotechnical scour number. Dashed line on Figure $2 b$ is the empirical scour number.

weight is the largest at any point during the test. The slope of equivalent scour depth versus equivalent stream power is defined as the 'geotechnical scour number'. The siltstone data from Figure 1 produced a geotechnical scour number of $3.96 \mathrm{e}-6$ $\mathrm{m} / \mathrm{W} / \mathrm{m}^{2}\left(0.00019 \mathrm{ft} / \mathrm{ft}-\mathrm{lb} / \mathrm{s} / \mathrm{ft}^{2}\right)$. The empirical scour number $\left(4.53 \mathrm{e}-06 \mathrm{~m} / \mathrm{W} / \mathrm{m}^{2}\right)$ is nearly within the $95 \%$ confidence interval of the regression, as shown on Figure $2 \mathrm{~b}$.

Geotechnical scour numbers for claystone, limestone, blocky siltstone, and sandstone were measured using the same procedure (Figure 3 ). The results were consistent with observed channel behavior suggesting that the modified slake durability test may be valuable for bridge scour evaluations. The geotechnical scour numbers in this paper were calculated for sedimentary rock types. We believe that the geotechnical scour number may represent a basic characteristic of earth materials that are cemented or indurated; it also may be a useful characteristic of cohesive soils.

\section{DISCUSSION AND CONCLUSIONS}

The oven drying component of the slake durability test induces rapid slaking in susceptible materials that is unrepresentative of most rock-bed channel conditions; therefore, it is sensible to eliminate oven drying from the ASTM D4644 procedure. The abrasion numbers of the two samples shown on Figure $1 \mathrm{~b}$ are nearly identical and represent the time-rate of material loss in response to the standard tumbling action of the slake durability test.

The slake durability test involves a standard drum rotating at $20 \mathrm{rpm}$. This combination of drum dimensions and rate of rotation produces an equivalent sample velocity of $0.147 \mathrm{~m} / \mathrm{s}(0.481 \mathrm{ft} / \mathrm{s})$. We considered plotting abrasion number as a function of equivalent sample velocity. We realized that modifying the rate of rotation of the slake durability drum would be needed to produce several equivalent velocities against which to evaluate sample response. We also realized that the equivalent energy was a function of the sample size, and that energy dissipated during test increments as the sample size diminished. Since we were representing hydraulic loading in terms of cumulative stream power, it was logical to represent the results of the modified slake durability test in equivalent stream-power terms. 


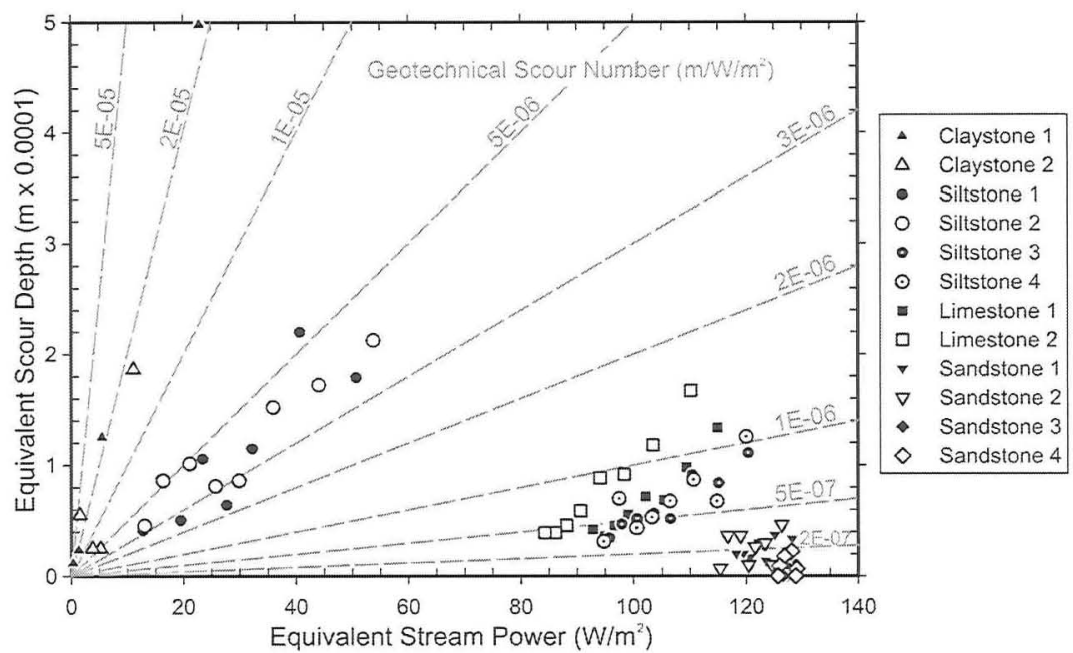

Figure 3. Modified slake durability results for four rock types from five locations. Claystone from San Juan County, Utah; thinly bedded siltstone from Shasta County, California (Siltstone 1 and 2; also in Figure 2); blocky siltstone from Polk County, Oregon; limestone from Jackson County, Florida; sandstone from San Juan County, Utah (Sandstone 1 and 2); sandstone from Montgomery County, New York. Dashed lines represent scour numbers in $\mathrm{m} / \mathrm{W} / \mathrm{m}^{2}$.

Geotechnical scour numbers are not correlatable with the headcut erodibility index (NRCS, 2001) or the erodibility index method (Annandale, 2006). Geotechnical scour numbers are rates of rock material wear as a function of energy dissipation expressed as equivalent stream power accumulated over a period of time. The two index methods use threshold values to compare properties of earth materials (soil and rock) to peak discharge expressed as stream power. The threshold approach also is used by Richardson and Davis (2001) for evaluating scour of sand-bed channels at bridge openings. Threshold approaches imply that scour does not occur at all at flow conditions less than the threshold and that scour holes develop rapidly after the threshold is reached or exceeded. Peak velocity is used as the threshold hydraulic parameter for sand-bed channels (Richardson and Davis, 2001), whereas peak stream power is used as the threshold hydraulic parameter for rock-bed channels (NRCS, 2001; Annandale, 2006). Furthermore, the headcut erodibility index is not suited for channels without overfalls (NRCS, 2001, p. 32).

The erodibility index method uses stream power for turbulent flow in the nearbed region (Annandale, 2006, p. 121-141) rather than conventional stream power as the product of hydraulic shear stress and flow velocity. Available stream power with depth into a scour hole is calculated on the basis of the maximum possible scour depth using earth material with negligible scour resistance and the procedures described in Richardson and Davis (2001) to estimate the maximum possible scour depth (Annandale, 2006, p. 256-257). The erodibility index method predicts the depth 
of scour as the depth at which the available stream power decreasing into the scour hole equals the equivalent resisting stream power of the earth material of the channel with the understanding that the ultimate scour hole can develop during a single discharge event if the threshold stream power is exceeded. Similarly, no scour occurs if the threshold stream power is not exceeded. The erodibility index value of the siltstone from the Sacramento River at Redding, CA, represented in Figures 1 and 2 is 0.1555 resulting in a threshold stream power of $0.2476 \mathrm{~kW} / \mathrm{m}^{2}$. The calculated applied stream power is $0.1989 \mathrm{~kW} / \mathrm{m}^{2}$. Thus, no scour would be predicted by the erodibility index method even though $1.52 \mathrm{~m}(5 \mathrm{ft})$ of pier scour was measured over a period of 33.8 years.

\section{ACKNOWLEDGMENTS}

The research described in this paper is part of a National Cooperative Highway Research Program project to develop guidelines for evaluating scour at bridge foundations or rock (NCHRP Project 24-29). The authors are grateful for review comments provided by Fred Kulhawy and Paul Santi, as well as by anonymous reviewers.

\section{REFERENCES}

Annandale, G.W. (2006). Scour Technology. McGraw-Hill, New York

ASTM. (2007). Standard Test Method for Density, Relative Density (Specific Gravity), and Absorption of Coarse Aggregate: ASTM Standard C127. American Society for Testing and Materials. ASTM International, West Conshohocken, PA (www.astm.org).

ASTM. (2008). Standard Test Method for Slake Durability of Shales and Similar Weak Rocks: ASTM Standard D4644. American Society for Testing and Materials, ASTM International, West Conshohocken, PA (www.astm.org).

Dickenson, S.E., and Baillie, M.W. (1999). Predicting Scour in Weak Rock of the Oregon Coast Range. Unpublished research report, Department of Civil, Construction, and Environmental Engineering, Oregon State University, Corvallis, OR. Final Report SPR 382, Oregon Department of Transportation and Report No. FHWA-OR-RD-00-04.

NRCS. (2001). Field Procedures Guide for the Headcut Erodibility Index: Chapter 52, Part 628, National Engineering Handbook, U.S. Department of Agriculture Natural Resources Conservation Service, 210-VI-NEH, rev, 37 p.

Richardson, E.V., and Davis, S.R. (2001). Evaluating Scour at Bridges. Hydrologic Engineering Circular 18, Federal Highway Administration, 4th Edition, Publication No. NHI 01-001, 378 p. 